\title{
Performance analysis of packed U-cell based inverter-fed five- phase induction motor drive using SINPWM technique
}

\author{
Ahmed Riyaz ${ }^{1}$, Pradip Kumar Sadhu' ${ }^{2}$, Atif Iqbal ${ }^{3}$, Md. Abdullah Ansari ${ }^{4}$ \\ ${ }_{1,2}$ Electrical Engineering Department, IIT (ISM) Dhanbad, India; \\ ${ }^{3}$ Electrical Engineering Department, College of Engineering, Qatar University, Doha-2713, Qatar, \\ ${ }^{4}$ Electrical Engineering Department, AMU, Aligarh, India
}

\begin{abstract}
Article Info
Article history:

\section{Keywords:}

Carrier signals

Harmonics

Packed U cell

Transient state
\end{abstract}

Received Nov 23, 2019

Revised Apr 26, 2020

Accepted Aug 3, 2020

\begin{abstract}
Induction motor is the backbone of current industrial applications. Multiphase machines can handle high power application easily. With the use of five-phase induction motor, advantage of both multi-phase and induction motor can be achieved. This paper presents analysis of five-phase seven level-based Induction motor system fed by packed U-cell based inverter. Modelling of five-phase induction motor is done with the help of mathematical equations using $\mathrm{d}-\mathrm{q}$ axis transformation. Inverter voltage output comes to be approximately sinusoidal with $18.07 \%$ Total Harmonic Distortion (THD). Induction motor with specified parameters is simulated under no-load condition and attains steady state conditions after transient state.
\end{abstract}

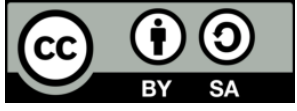

\section{Corresponding Author:}

Ahmed Riyaz

Electrical Engineering Department,

IIT (ISM)

Dhanbad, India

Email: riyazamu@gmail.com

\section{INTRODUCTION}

Multiphase systems are the focus of research in present days due to their intrinsic advantages compared to three-phase systems. Higher power handling capability, more fault tolerant, lesser torque ripples etc. are major advantage of the multi-phase system. With the increase of the number of phases, the power/torque per RMS ampere for the same volume machine can also be increased. Multiphase systems have huge potential in the area of generation, transmission and utilization [1]. The research on multiphase generators and synchronous machines has started recently $[2,3]$ but the research on multiphase induction machines has been done extensively and various studies related to this is available [4, 5]. The phase transformation was reported initially by S. P. Thompson in 1894 [6]. Of the total global electricity being consumed, motor system consumes about $43 \%$ to $46 \%$ and of which, Induction motor is preferred due to its robustness, more tolerant to faults, low cost, less maintenance and high speed [7-10]. In Industrial automation system, AC drives with adjustable speed system are also gaining popularity. In order to enhance the accuracy and reliability of the motor, proper control system with desired efficiency and performance is required. Controlling Induction motor involves maintaining the desired speed at steady state which can be done in many ways like: Stator and rotor voltage control, Frequency control, and Stator voltage and frequency control

Modern Power electronics converters are committed towards desired speed control and maintaining ripple free torque output at the same time. Conventionally, two level inverters were designed which are 
becoming obsolete due to high Total Harmonic Distortion (THD) and losses. Multilevel inverters (MLI) involves generating more than three output levels with the help of combination of DC sources and switches in order to improve THD, better power quality, reducing switching losses, etc. And due to these features, MLIs are being extensively utilized in Power system applications. Control scheme employing Pulse Width Modulation (PWM) technique have brought THD to a much lower extent which is discussed in [11-15].

With the Introduction of DC link MLIs, number of switches and gate driver circuits have been reduced. Some of the conventional MLI topologies include: Cascaded H-Bridge MLI, Neutral point or Diode clamped type MLI, Flying Capacitor MLI.

Cascaded H-Bridge topology uses switches and capacitors cascaded to amplify the output levels. Each H-bridge gives different voltages like zero, positive and negative of DC source. One major problem with this topolgy is the availability of Isolated DC sources which requires transformers[16]. Second problem is the switch count which also pose limitations on practical levels [17-18]. Three level Diode Clamped MLI was first proposed by [19]. It involves capacitors clamped to produce output voltage levels. Two obvious problems with this topology are: Unbalance in the capacitor voltages and other is the excessive use of clamping diodes. Flying Capacitor based MLI has certain advantages over other topologies like, redundancies in the voltage levels, which can be obtained more than one switch combinations [20].

This paper focuses on recently designed Packed U-Cell inverter topology which outperforms the above described in terms of power quality and component count [21]. Each U cell is comprised of one source and two switches. U-cells are connected in parallel fashion to increase output levels. Further, seven level output of the inverter is fed to five phase Induction motor. The complete model is designed and simulated in MATLAB/Simulink.

Section II describes the implementation of Multi-level output using Packed U-Cell and mathematical modelling of five phase Induction motor using 5-2 phase transformation. Section III analyses the performance of combined Inverter fed Induction motor system. Finally, Section IV concludes the paper.

\section{CONSTRUCTION AND WORKING PRINCIPLE}

\subsection{Five phase seven level packed $U$-cell inverter}

The described topology is a combined form of many $U$ cells in which each cell comprises of one Capacitor source and two Power electronics switches (Figure 1) [22]. Cascading additional U cells result in additional voltage levels which is shown in Figure 2.

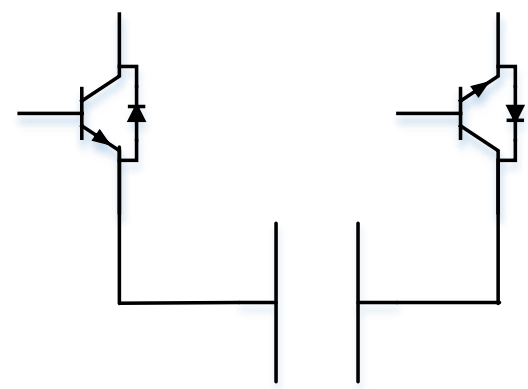

Figure 1. Unit U cell

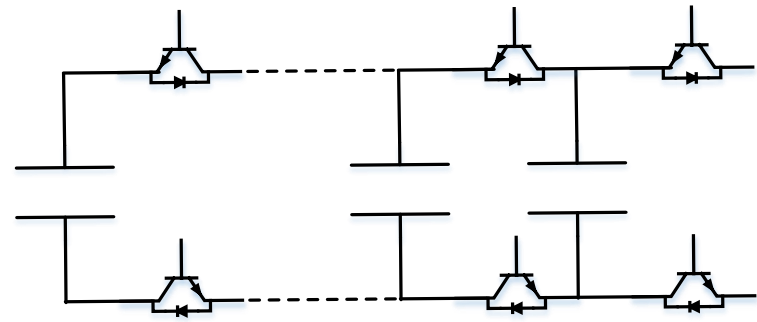

Figure 2. Cascaded U cells

The proposed seven level topology is shown in Figure 3. The upper capacitor is charged with DC voltage V1 and lower capacitor is charged with one-third of V1 equal to V2. Total six switches are employed of which S1', S2' and S3' switches are complimentary of S1, S2 and S3 respectively. Other conventional topologies, like cascaded H-bridge configuration requires many transformers for producing isolated DC source. For removing this drawback, transformer less configuration is developed. Table 1 shows the possible voltage levels with switching sequence [23]. Among eight voltage states, two zero states are redundant and other six are active states. 


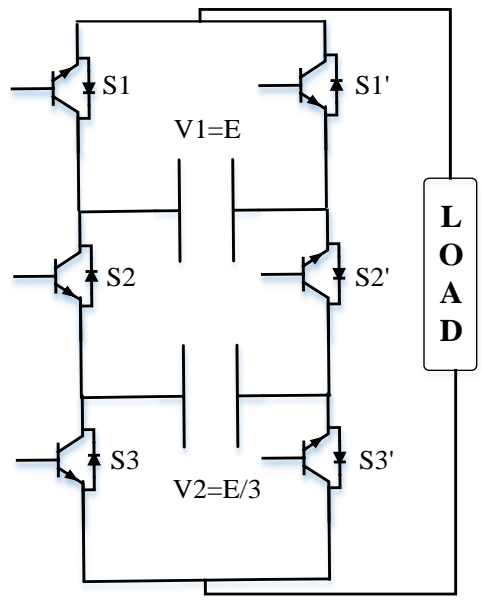

Table 1. Switching sequence vs voltage levels of the

\begin{tabular}{cccccccc}
\multicolumn{7}{c}{ proposed seven level topology } \\
\hline State & $\mathrm{V}_{\mathrm{o}} \downarrow$ & $\mathrm{S}_{1}$ & $\mathrm{~S}_{2}$ & $\mathrm{~S}_{3}$ & $\mathrm{~S}_{1}$, & $\mathrm{S}_{2}$, & $\mathrm{S}_{3}$, \\
\hline 1 & $\mathrm{~V} 1$ & 1 & 0 & 0 & 0 & 1 & 1 \\
2 & $\mathrm{~V} 1-\mathrm{V} 2$ & 1 & 0 & 1 & 0 & 1 & 0 \\
3 & $\mathrm{~V} 2$ & 1 & 1 & 0 & 0 & 0 & 1 \\
4 & 0 & 1 & 1 & 1 & 0 & 0 & 0 \\
5 & 0 & 0 & 0 & 0 & 1 & 1 & 1 \\
6 & $-\mathrm{V} 2$ & 0 & 0 & 1 & 1 & 1 & 0 \\
7 & $\mathrm{~V} 2-\mathrm{V} 1$ & 0 & 1 & 0 & 1 & 0 & 1 \\
8 & $-\mathrm{V} 1$ & 0 & 1 & 1 & 1 & 0 & 0 \\
\hline
\end{tabular}

Figure 3. Proposed seven level topology

\subsection{Five phase squirrel cage induction motor}

Induction motors work on the principle of relative motion between stator magnetic field and rotor conductors. The rotating magnetic field is responsible for rotation of rotor with speed equal to slip speed. Unlike three phase, the AC supply of the stator in five phase is displaced by $72^{\circ}$ in space which is shown in Figure 4. And in case of squirrel cage rotor, the EMF developed produces current which results in interaction of two magnetic fields. The torque developed causes the rotor to rotate on its axis. General formula for spatial displacement angle for any balanced n-phase AC machine is $2 \pi / \mathrm{n}$.

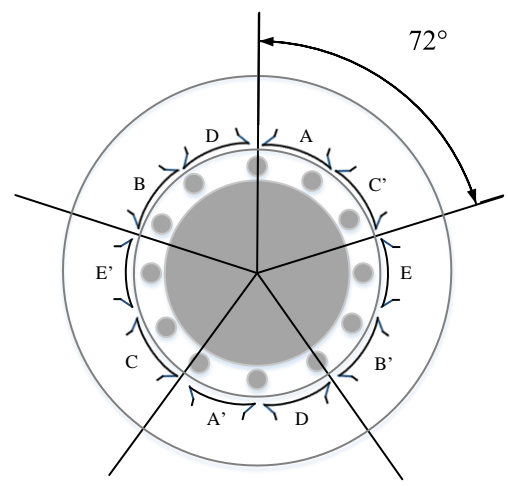

Figure 4. Five phase winding arrangement

Analysing the dynamic behavior of the induction motor requires proper mathematical model of the whole system. And since the time dependent nature of motor parameters complicates the differential equation. One way is to somehow make the equation time independent. Rotating magnetic field produced by five phase AC can be reduced to simple two orthogonal d-q axis. In other words, stator as well as rotor fluxes, voltage, etc. are calculated with respect to other reference frame i.e. d-q axis.

Assuming that the arbitrary reference frame is rotating with angular speed $\omega_{a}$, Induction motor steady state model equation transformed into d-q axis frame is given below [24]:

For stator:

$$
\begin{aligned}
& v_{q s}=R_{s} i_{q s}+\omega_{a} \psi_{d s}+p \psi_{q s} \\
& v_{d s}=R_{s} i_{d s}-\omega_{a} \psi_{q s}+p \psi_{d s} \\
& v_{x s}=R_{s} i_{x s}+p \psi_{x s} \\
& v_{y s}=R_{s} i_{y s}+p \psi_{y s}
\end{aligned}
$$


$v_{o s}=R_{s} i_{o s}+p \psi_{o s}$

$\psi_{q s}=\left(L_{l s}+L_{m}\right) i_{q s}+L_{m} i_{q r}$

$\psi_{d s}=\left(L_{l s}+L_{m}\right) i_{d s}+L_{m} i_{d r}$

$\psi_{x s}=L_{l s} i_{x s}$

$\psi_{y s}=L_{l s} i_{y s}$

$\psi_{o s}=L_{l s} i_{o s}$

For rotor:

$$
\begin{aligned}
& v_{q r}=R_{r} i_{q r}+\left(\omega_{a}-\omega\right) \psi_{d r}+p \psi_{q r} \\
& v_{d r}=R_{r} i_{d r}-\left(\omega_{a}-\omega\right) \psi_{q r}+p \psi_{d r} \\
& v_{x r}=R_{r} i_{x r}+p \psi_{x r} \\
& v_{y r}=R_{r} i_{y r}+p \psi_{y r} \\
& v_{o r}=R_{r} i_{o r}+p \psi_{o r} \\
& \psi_{q r}=\left(L_{l r}+L_{m}\right) i_{q r}+L_{m} i_{q s} \\
& \psi_{d r}=\left(L_{l r}+L_{m}\right) i_{d r}+L_{m} i_{d s} \\
& \psi_{x r}=L_{l r} i_{x r} \\
& \psi_{y r}=L_{l r} i_{y r} \\
& \psi_{o r}=L_{l r} i_{o r}
\end{aligned}
$$

Finally the Torque and rotor speed equation:

$$
\begin{aligned}
T_{e} & =P L_{m}\left[i_{d r} i_{q s}-i_{d s} i_{q r}\right] \\
\omega_{r} & =\int \frac{P}{2 J}\left(T_{e}-T_{l}\right)
\end{aligned}
$$

As can be seen from the above equations, $\mathrm{x}-\mathrm{y}-\mathrm{o}$ components are present along d-q axis components. $\mathrm{x}-\mathrm{y}$ components present in rotor side can be omitted for further calculation because of short-circuited rotor. Also zero component is also not present because of star connection of stator winding and short-circuited rotor windings. This reduces the five phase system to simply two phase system in arbitrary reference frame. The KVL equation is illustrated in Figure 5.

Input to the five phase induction motor is given by seven level inverter described above.

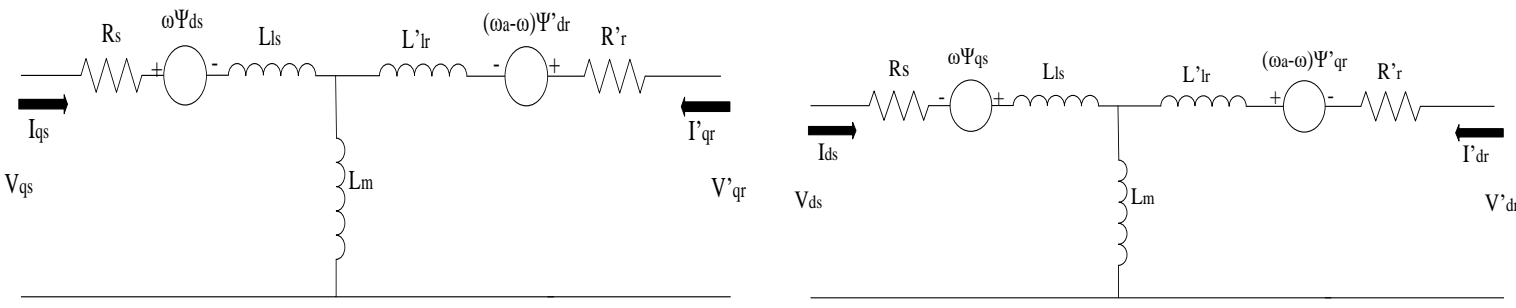

(a)

(b)

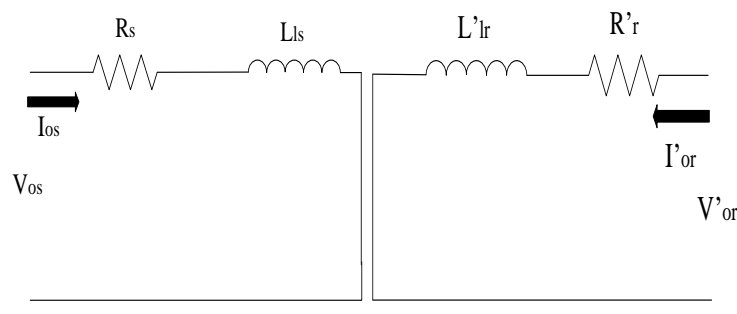

(c)

Figure 5. Equivalent circuit diagram, (a) q-axis, (b) d-axis and (c) o-axis 
Balanced five phase sinusoidal AC is given to the stator. Each phase is displaced by $72^{\circ}$ or $\frac{2 \pi}{5}$ radian. The equation is given below along with Figure 6.

$$
\begin{aligned}
& V_{a}=V_{o} \sin (\omega t) \\
& V_{b}=V_{o} \sin \left(\omega t-\frac{2 \pi}{5}\right) \\
& V_{e}=V_{o} \sin \left(\omega t+\frac{2 \pi}{5}\right) \\
& V_{c}=V_{o} \sin \left(\omega t-\frac{4 \pi}{5}\right) \\
& V_{d}=V_{o} \sin \left(\omega t+\frac{4 \pi}{5}\right)
\end{aligned}
$$

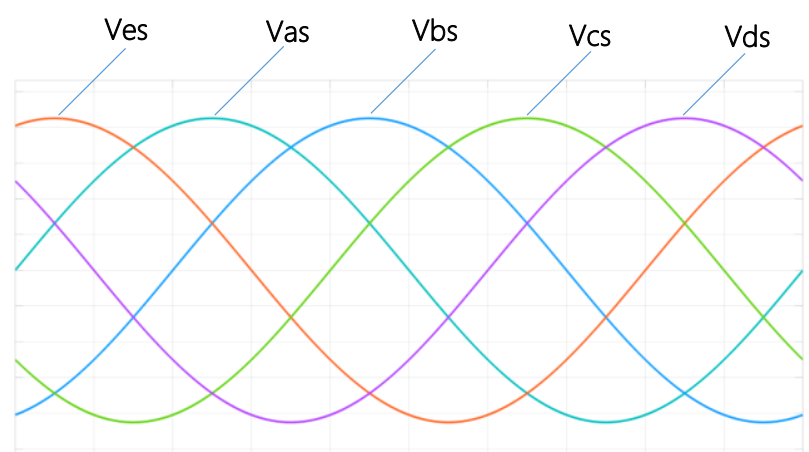

Figure 6. Five phase balanced Sinusoidal AC signal

\section{SIMULATION AND PERFORMANCE ANALYSIS:}

Power electronic switches like IGBTs are triggered by providing gate signals. Here, we are using sine Pulse Width Modulation technique in which pure sinusoidal reference signal is compared with Alternate Phase Opposition Disposed (APOD) carrier signals to obtain the required gate pulse (Figure 7). Other circuit parameters of Packed U cell Inverter as well as Induction motor is given in Table 2 and 3.

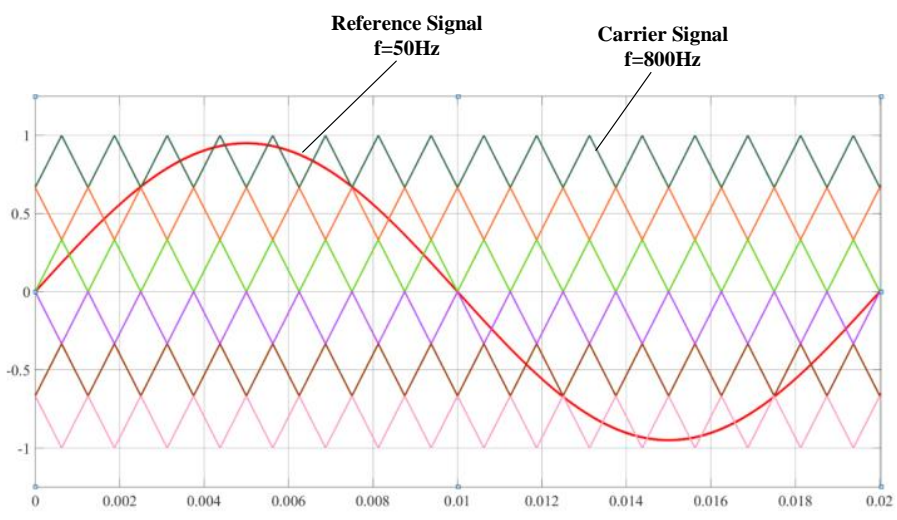

Figure 7. APOD carrier signals vs sine reference signal

Table 2. Seven level packed u cell circuit parameters

\begin{tabular}{cc}
\hline Parameters & Value \\
\hline Voltage Source (V1) & $200 \mathrm{~V}$ \\
Capacitor Charge (V2) & $200 / 3 \mathrm{~V}$ \\
Reference signal frequency & $50 \mathrm{~Hz}$ \\
Carrier Frequency & $800 \mathrm{~Hz}$ \\
Amplitude Modulation Index & 0.95 \\
Switch & IGBT Ron $=1 \mathrm{~m} \Omega$ \\
\hline
\end{tabular}

Performance analysis of packed u-cell based inverter-fed five-phase induction motor ... (Ahmed Riyaz) 
Table 3. Five phase induction motor rating

\begin{tabular}{cc}
\hline Parameters & Value \\
\hline Rated Frequency & $50 \mathrm{~Hz}$ \\
Number of Poles & 4 \\
Stator Resistance (Rs) & $2.8 \Omega$ \\
Rotor Resistance (Rr) & $1.9 \Omega$ \\
Stator Inductance (Lls) & $5 \mathrm{mH}$ \\
Rotor Inductance (Llr) & $24 \mathrm{mH}$ \\
Mutual Inductance (Lm) & $150 \mathrm{mH}$ \\
Moment of Inertia (J) & $0.009 \mathrm{kgm}^{2}$ \\
\hline
\end{tabular}

Since Balanced Five phase Input AC voltage is required for normal operation of Induction motor under steady state. But, also the output of Inverter circuit is not purely sinusoidal. So, it is desired to minimize the losses which is in the form of harmonics. Total Harmonic Distortion (THD) is the term used to evaluate percent of unwanted harmonic frequency components present in the signal.

$$
T H D=\sqrt{\frac{V_{r m s}^{2}-V_{1}^{2}}{V_{1}}}
$$

where $V_{r m s}$ and $V_{1}$ are the RMS and fundamental component of output voltage respectively. Simple Block diagram representing inverter plus motor section is illustrated in Figure 8. Simulink model of Induction motor is given in Appendix for further reference.

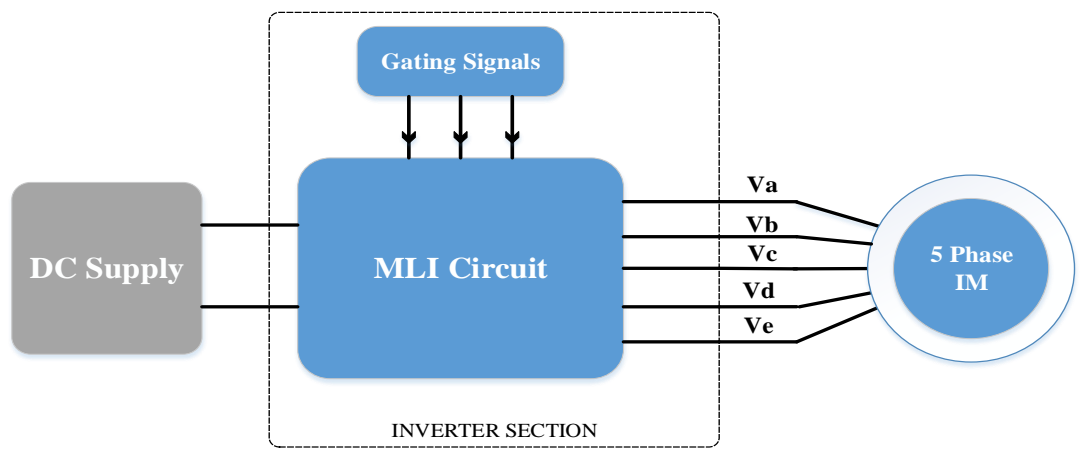

Figure 8. Block Diagram showing complete system model

\section{RESULTS AND DISCUSSION:}

The simulation is done in MATLAB/Simulink environment, the Simulink model is depicted in Figure 13 (Appendix). On running the complete model in Simulink, it is found that output Inverter waveform resembles very much near to the Sinusoidal signal as shown in Figure 9. THD of output voltage is $18.07 \%$ which is sufficiently low for the Induction motor stable operation as can be seen in Figure 10.

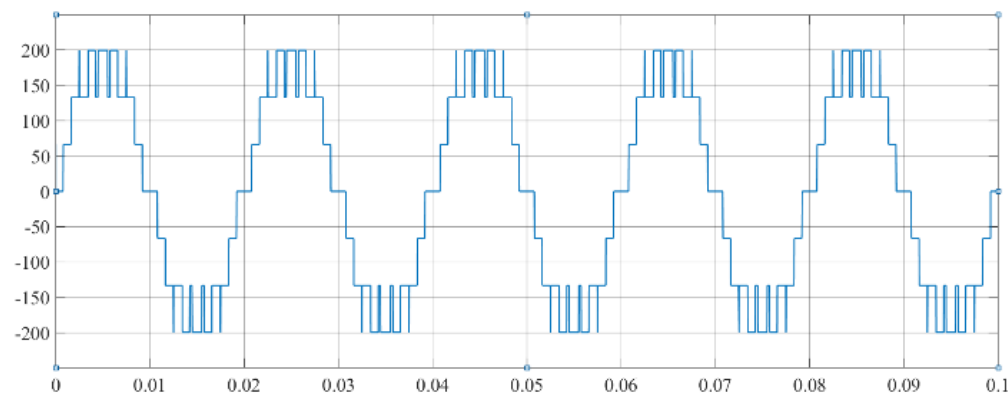

Figure 9. Inverter output voltage waveform 


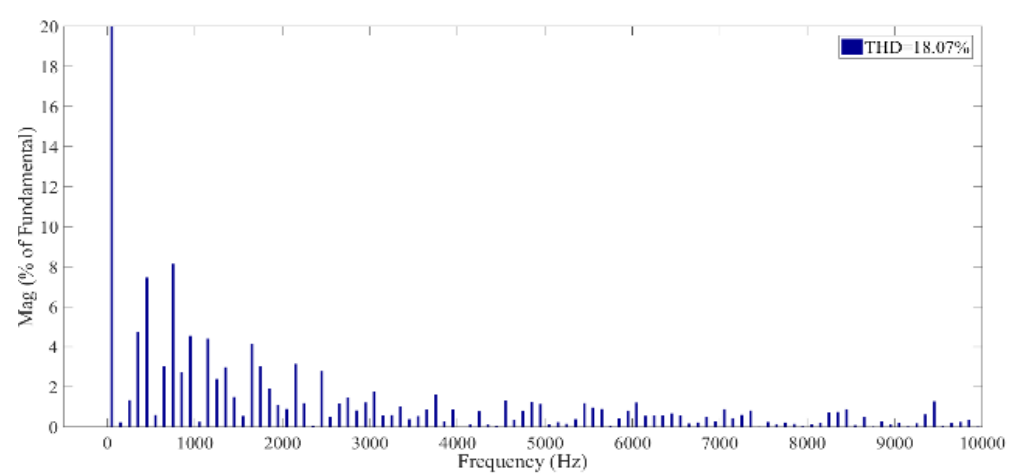

Figure 10. THD of output voltage waveform

Feeding the seven level inverter output to five phase Inductor motor results in gradual development of torque which consequently after small transient state achieves stable state which is depicted in Figure 11. Similarly, rotor speed attains near synchronous speed after sufficient transient state which is around 0.1 seconds in this case as shown in Figure 12. Both speed and torque are analyzed for No-load condition.

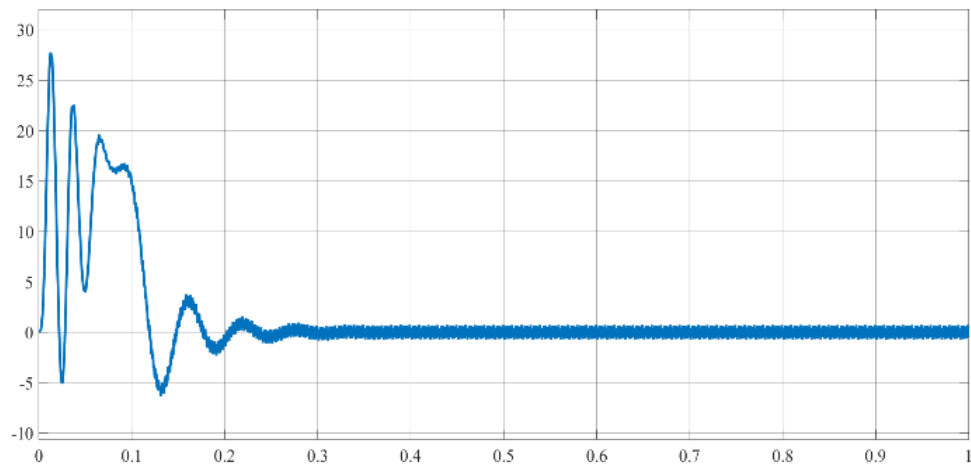

Figure 11. Electromagnetic torque $(\mathrm{Nm})$ at no-load condition

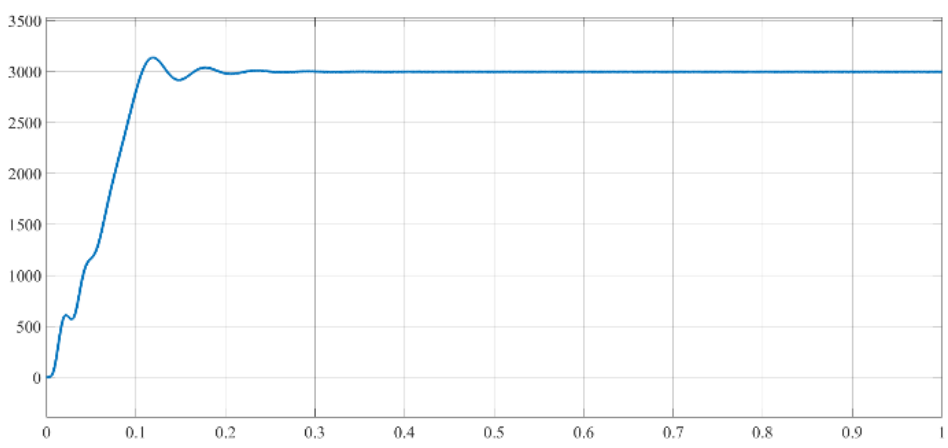

Figure 12. Rotor Speed (rpm) at no-load condition

\section{CONCLUSION:}

This paper describes Simulation model of running five phase Induction motor system with the output fed from seven level Packed-U cell Multi level inverter. The model is developed employing blocks taken from Simpower system Library. Inverter output voltage along with THD is analyzed. Induction motor speed attains rated value after undergoing transient state and torque developed initially moves the rotor and settles down after steady state in absence of Load torque. The model can be extended to n-phase Induction motor system.

Performance analysis of packed u-cell based inverter-fed five-phase induction motor ... (Ahmed Riyaz) 


\section{ACKNOWLEDGEMENT:}

This publication was made possible by Qatar University High Impact Research grant \# [QUHICENG-19/20-2] from the Qatar University. The statements made herein are solely the responsibility of the authors.

APPENDIX

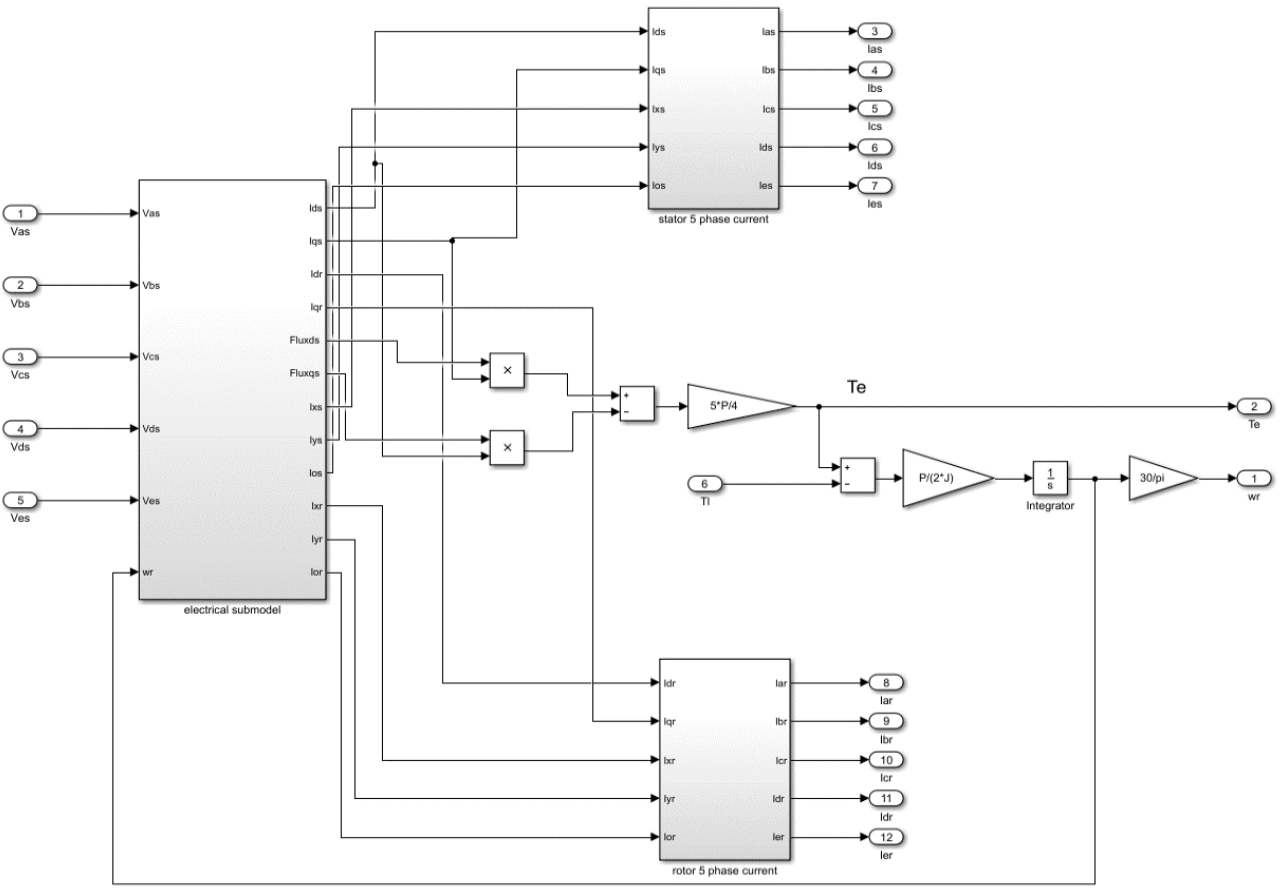

(a)

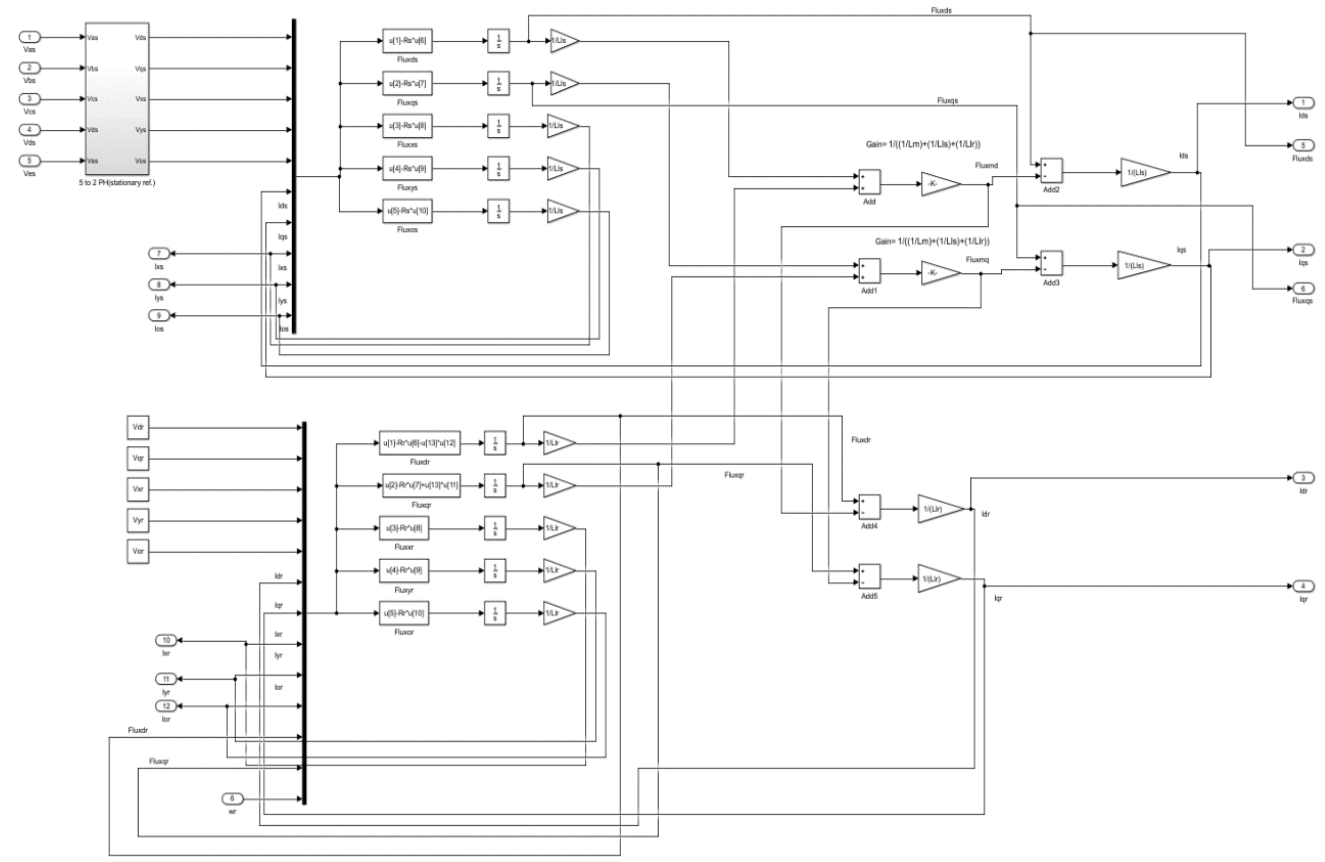

(b)

Figure 13 (a) Complete simulink model of five phase induction motor, (b) Electrical sub-model 


\section{REFERENCES}

[1] E. Levi, "Multiphase electric machines for variable-speed applications," IEEE Trans. Ind. Electron., vol. 55, no. 5, pp. 1893-1909, 2008

[2] T. Kamel, D. Abdelkader, B. Said, S. Padmanaban, A. Iqbal, “A. Extended Kalman Filter Based Sliding Mode Control of Parallel-Connected Two Five-Phase PMSM Drive System," Electronics, Vol. 7, No. 2, 14, 2018.

[3] A. Bruyere, E. Semail, A. Bouscayrol, F. Locment, J. M. Dubus, and J. C. Mipo, "Modeling and control of a seven-phase claw-pole Integrated Starter Alternator for micro-hybrid automotive applications," 2008 IEEE Veh. Power Propuls. Conf. VPPC 2008, pp. 1-6, 2008.

[4] Rangari, S.C, Suryawanshi, H.M, Renge. M, "New Fault-Tolerant Control Strategy of Five-Phase Induction Motor with Four-Phase and Three-Phase Modes of Operation," Electronics, Vol. 7, 159, 2018.

[5] E Levi, M Jones, SN Vukosavic, A Iqbal, HA Toliyat, "Modeling, control, and experimental investigation of a five-phase series-connected two-motor drive with single inverter supply," IEEE Transactions on Industrial Electronics, Vol. 54, No. 3, pp. 1504-1516, 2007.

[6] J. E. Parton, "A general theory of phase transformation," Proc. IEE-Part IV Inst. Monogr., vol. 99, no. 2, pp. 1223, 1952.

[7] T. Poompavai and P. Vijayapriya, "Comparative analysis of modified multilevel DC link inverter with conventional cascaded multilevel inverter fed induction motor drive," Energy Procedia, vol. 117, pp. 336-344, 2017.

[8] R. M. Patil, V. P. Dhote, and A. Thosar, "Comparative Analysis of Three Phase 5,7 9 Level Inverter Using PDPWM Technique," Proc. - 2018 Int. Conf. Smart Electr. Drives Power Syst. ICSEDPS 2018, pp. 323-328, 2018.

[9] A. Kouzou, P. Saifullah, A. Iqbal and H. Abu-Rub, "Performance analysis of a five-phase induction motor under unbalanced voltage supply," 10th International Multi-Conferences on Systems, Signals \& Devices 2013 (SSD13), Hammamet, 2013, pp. 1-8.

[10] P. Panagis, F. Stergiopoulos, P. Marabeas, and S. Manias, 'Comparison of state-of-the-art multilevel inverters', PESC Rec. - IEEE Annu. Power Electron. Spec. Conf., pp. 4296-4301, 2008.

[11] M. A. Perez, S. Bernet, J. Rodriguez, S. Kouro, and R. Lizana, 'Circuit topologies, modeling, control schemes, and applications of modular multilevel converters', IEEE Trans. Power Electron., vol. 30, no. 1, pp. 4-17, 2015.

[12] K. Corzine and Y. Familiant, "A new cascaded multilevel Hbridge drive," IEEE Tran.Power Electron., vol. 17, no. 1, Jan. 2002, pp. 125-131

[13] R. Stala, "A natural DC-link voltage balancing of diode-clamped inverters in parallel systems", IEEE Trans. Ind. Electron., Vol. 60, No. 11, pp. 5008-5018, Nov (2013).

[14] S. Nagaraja, D.V. Ashok Kumar and C. Sai Babu, "New Multilevel Inverter Topology with reduced number of Switches using Advanced Modulation Strategies", International Conference on Power, Energy and Control (ICPEC), (2013).

[15] H. Abu-Rub, A. Iqbal, and J. Guzinski, "High performance control of AC drives with MATLAB/Simulink models," John Wiley \& Sons. United Kingdom, 2012.

[16] M. Tariq, M. Meraj, A. Azeem, A. I. Maswood, A. Iqbal, and B. Chokkalingam, "Evaluation of Level-Shifted and Phase-Shifted PWM Schemes for Seven Level Single-Phase Packed U Cell Inverter," CPSS Trans. Power Electron. Appl., vol. 3, no. 3, pp. 232-242, 2018.

[17] M. Trabelsi, S. Bayhan, S. S. Refaat, H. Abu-rub, and L. Ben, "Multi-objective model predictive control for gridtied 15-level packed U cells inverter," 2016 18th European Conference on Power Electronics and Applications (EPE'16 ECCE Europe), 2016.

[18] Dhara, Saumen \& Shrivastav, Alok \& Sadhu, Pradip \& Ganguly, Ankur, "A Fault Current Limiter Circuit to Improve Transient Stability in Power System," International Journal of Power Electronics and Drive Systems (IJPEDS). Vol. 7, No. 3, pp. 769-780, 2016.

[19] A. Nabae, I. Takahashi, and H. Akagi, "A New Neutral-Point-Clamped PWM Inverter," IEEE Trans. Ind. Appl., vol. IA-17, no. 5, pp. 518-523, 1981

[20] Fang Lin Luo and Hong Ye, Advanced DC/AC inverters: applications in renewable energy, Crc Press. 2013.

[21] F. Sebaaly, H. Vahedi, H. Y. Kanaan, and K. Al-Haddad, "Experimental Design of Fixed Switching Frequency Model Predictive Control for Sensorless Five-Level Packed U-Cell Inverter," IEEE Trans. Ind. Electron., vol. 66, no. 5, pp. 3427-3434, 2019.

[22] A. N. Babadi, O. Salari, M. J. Mojibian, and M. T. Bina, "Modified Multilevel Inverters with Reduced Structures Based on PackedU-Cell," IEEE J. Emerg. Sel. Top. Power Electron., vol. 6, no. 2, pp. 874-887, 2018.

[23] A. Ben Zid and F. Bacha, "Simulation of a single-phase seven-level packed U cells rectifier: A comparative study between PWM control and hysteresis control," 2018 9th Int. Renew. Energy Congr. IREC 2018, no. Irec, pp. 1-6, 2018.

[24] M. R. Arahal, M. J. Duran, F. Barrero, and S. L. Toral, "Stability analysis of five-phase induction motor drives with variable third harmonic injection," Electr. Power Syst. Res., vol. 80, no. 12, pp. 1459-1468, 2010. 